\title{
Dünya ve Türkiye'de Yağlı Tohum ve Ham Yağ Üretimine Bir Bakış
}

\author{
Bihter ONAT ${ }^{1} \quad$ Halis ARIOĞLU ${ }^{2} \quad$ Leyla GÜLLÜOĞLU ${ }^{2} \quad$ Cemal KURT $^{2} \quad$ Halil BAKAL $^{2}$ \\ ${ }^{1}$ Ç.Ü. Kozan MYO, Kozan-Adana \\ ${ }^{2}$ Ç.Ü. Ziraat Fakültesi, Tarla Bitkileri Bölümü, Adana \\ $\triangle$ : halis@cukurova.edu.tr
}

Geliş (Received): 03.11.2017

Kabul (Accepted): 15.12.2017

\begin{abstract}
ÖZET: İçerdikleri yă̆, protein, karbonhidrat, mineral maddeler ve vitaminler nedeniyle, insan ve hayvan beslenmesinde önemli bir yere sahip olan yağlı tohumlar, aynı zamanda, sanayi sektörü için de önemli bir hammadde kaynağını oluşturmaktadır. Yağlı tohumlu bitkiler çok yönlü kullanım alanlarına sahip, asrın harika bitkileri olarak bilinmektedir. Yağlı tohumlardan elde edilen yağlar, insan beslenmesinde önemli bir enerji kaynağını oluşturmaktadır. Hayvansal kökenli yağların üretiminin pahalı ve yeterli olmaması nedeniyle, insan beslenmesi için gereksinim duyulan yağların büyük bir kısmı (\%92.1), bitkisel kökenli yağlardan karşılanmaktadır. Yeryüzünde tohumlarında yağ içeren çok sayıda bitki olmasına rağmen, bugün sanayide işlenerek tohumlarından yağ elde edilen bitkilerin başında; Soya, ayçiçeği, çiğit (pamuk), kolza, yerfıstığı, susam, aspir, hintyağı, haşhaş, keten, kenevir, jojoba, mısır (mısır özünden), zeytin, hurma (palm) ve Hindistan cevizi (coco) gelmektedir. Yağlı tohumlu bitkilerin ham yağ üretimi yanında, çok değişik faydaları bulunmaktadır. Soya ve yerfistığı gibi baklagiller familyasına dahil yağlı tohumlu bitkiler, havanın serbest azotunu toprağa bağladıkları için, yetiştirildikleri bölgelerde tarım topraklarına önemli faydalar sağlamaktadır.

2016 yılı verilerine göre, dünya yağlı tohum üretimi 554 million ton and ham yağ üretimi ise 187 milyon ton olarak gerçekleşmiştir. Aynı dönemde Türkiye'de yağlı tohum üretimi 2.9 milyon ton ve ham yağ üretimi de 786 bin ton olmuştur.

Anahtar kelimeler: Yağlı tohumlar, yağlı tohum üretimi, bitkisel yağ, bitkisel yağ üretimi
\end{abstract}

\section{Oil Seeds and Crude Oil Production in the World and in Turkey;}

ABSTRACT: The oil seeds contain high level of oil, protein, carbohydrate, mineral and vitamins. For this reason, it is an important source of edible oil and protein for human nutrition. Also, it is an important for the industrial as a raw material. The oil crops use many different purposes. For this reason it is called as a wonder crop of the century. The oils produced from the oil crops are used as a source of energy for the human nutrition. Most of the oils (92.1\%) used for human consumption comes from oil crops due to higher production cost and limit supply of animal fats. There are plenty of oil seed crops such as soybean, sunflower, rapeseed, peanut, sesame, safflower palm, olive and coconut for crude oil production. Beside crude oil supply, oil crops have other extra benefits. Soybean and peanut are legume crops and supply nitrogen to the soils by symbiotic nitrogen fixation. The oil seeds production was 554 million tons and vegetable oil production was 187 million tons in the world in 2016. In the same period the oil seeds and vegetable oil production was 2.9 million tons and 786.000 tons, respectively in Turkey.

Key words: Oil crops, Oil seed production, Vegetable oil, Vegetable oil production

\section{GíRis}

İçerdikleri yağ, protein, karbonhidrat, mineral maddeler ve vitaminler nedeniyle, insan ve hayvan beslenmesinde önemli bir yere sahip olan yağlı tohumlar, aynı zamanda, sanayi sektörü için de önemli bir hammadde kaynağını oluşturmaktadırlar. Yağlı tohumlu bitkiler çok yönlü kullanım alanlarına sahip, asrın harika bitkileridir. Hayvansal kökenli yağların üretiminin pahalı ve yeterli olmaması nedeniyle, insan beslenmesi için mutlak surette gereksinim duyulan yağların büyük bir kısmı, bitkisel kökenli yağlardan karşılanmaktadır (Kolsarıcı ve ark., 2015).

2016 yılı verilerine göre, dünya ham yağ üretimi toplam 203 milyon ton olup, bunun \%92.1'i (187.0 milyon ton) yağlı tohumlardan, \%7.9'u (16.0 milyon ton) ise hayvansal kaynaklardan sağlanmıştır (Anonim, 2016a). Kişi başına yağ tüketim ise $29.0 \mathrm{~kg}$ olarak gerçekleşmiştir (üretilen yağın tamamının gıda amaçlı kullanılacağı varsayılmıştır). Aynı dönemde ülkemizde yerli kaynaklardan toplam 966 bin ton bitkisel ham yağ üretilmiştir (180 bin ton zeytinyağı üretimi de dahil edilmiştir). Kişi başına yıllık yă̆ tüketimi ise $21.9 \mathrm{~kg}$ olarak gerçekleşmiştir (Anonim, 2016b).

Yağlı tohumların içeriğinde bulunan yağın alınması sonucu geriye kalan küspe, ham protein oranı bakımından oldukça yüksek değerlere sahip olduğu için, hayvan beslenmesi bakımından çok önemlidir. Yılda toplam bir milyar ton karma yem üretildiği ve yaklaşık 300 milyon ton yağlı tohum küspesi kullanıldığı göz önüne alındığında, yağlı tohumlu bitkilerin dünya tarımı bakımından ne derece önemli olduğu ortaya çıkmaktadır (Karakuş, 2014).

Ayrıca, bitkisel kökenli yağların; bio-dizel üretiminde ve sanayide hammadde olarak kullanılması da göz önüne alındığında, yağlı tohumlu bitkilerin üretiminin önemi daha da artmaktadır. Soya ve Yerfistığı gibi yağlı tohumlu bitkiler baklagiller familyasından oldukları için, havanın serbest azotunu toprağa bağlayarak, toprakların verimliliğinin artmasına ve süreklilik kazanmasına katkıda bulunurlar (Arığlu 
ve ark., 2010).

Dünya üzerinde yabani ve kültüre alınarak yetiştirilen tek ve çok yıllık birçok bitkinin etli meyve kısmı, çoğunlukla da tohumları değişik oranlarda yağ içermektedirler. 2016 yılı verilerine göre; dünya yağlı tohum üretim miktarları toplam 554 milyon ton olarak gerçekleşmiştir (Zeytin, Hurma ve Hindistan cevizi üretimi hariç). Aynı dönemde ülkemizde ise bu miktar ancak 2.698.000 tonlara ulaşabilmiştir. Yağlı tohum üretiminin yeterli olmaması nedeniyle, aynı dönemde, yurt dışından 3.1milyon ton yağlı tohum ithal edilmiştir. Bugün için ülkemizde toplam ekilebilen alanlar içerisinde yağlı tohumlu bitkilerin payı sadece $\% 4.0$ gibi düşük bir oranda iken, bu değer ABD'de \%20.9, Çin'de $\% 19.2$, Brezilya'da \%28.2, Hindistan'da \%27.9 ve Arjantin'de \%21 olarak gerçekleşmiştir. AB ülkelerinde ise bu oranın \%30 dolaylarında olduğu bildirilmektedir (Anonim, 2016a).

Yeryüzünde tohumlarında yă içeren çok sayıda bitki olmasına rağmen, bugün sanayide işlenerek tohumlarından yağ elde edilen bitkilerin başında; Soya, ayçiçeği, çiğit (pamuk), kolza, yerfistı̆̆ı, susam, aspir, hintyağı, haşhaş, keten, kenevir, jojoba, mısır (mısır özünden), zeytin, hurma ve Hindistan cevizi gelmektedir. Bunlar içerisinden; Çiğit, haşhaş, keten, kenevir ve misır yağ elde etme amaçlı yetiştirilen bitkilerden olmayıp, yan ürün olarak tohumlarından yağ elde edilmektedir. Ayrıca; Jojoba, zeytin, hurma ve Hindistan cevizi gibi bitkiler çok yıllık olup, diğerleri tek yıllık olarak yetişmektedir. Sahip olduğu farklı iklim özellikleri nedeniyle Türkiye'de, Jojoba, Hurma ve Hindistan cevizi dışındaki yağlı tohumlu bitkilerin tamamı başarıyla yetişebilmektedir (Arıoğlu, 2014).

\section{Yağlı tohumlu bitkiler ve önemi}

Dünya üzerinde yabani ve kültürel olarak yetiştirilen tek ve çok yıllık birçok bitkinin etli meyve kısmı, çoğunlukla da tohumları değişik oranlarda yağ içermektedirler. Tek yıllık bitkilerin başında; Ayçiçeği, Çiğit, Soya, Yerfistığı, Susam, Kolza, Aspir, Haşhaş ve Hintyăğ Hindistan cevizi (coco) ve Hurma (palm) gelmektedir. İçerdikleri yağ, protein, karbonhidrat, mineral maddeler ve vitaminler nedeniyle, insan ve hayvan beslenmesinde önemli bir yere sahip olan yağlı tohumlar, ayn zamanda, sanayi sektörü için de önemli bir hammadde kaynağını oluşturmaktadırlar. Sahip oldukları değerli içerik maddeleri nedeniyle, çok değişik kullanım alanlarına sahiptirler. Yağlı tohumlu bitkilerin önemi ana başlıklar halinde aşağıda maddeler halinde sıralanmış̧tır (Arıŏlu, 2014).

- Yağ Üretiminde Kullanılır,

- Karma Yem Üretiminde Kullanılır,

- Toprak Verimliliğgine Katkı Sağlarlar,

- Yeşil Yem Olarak Hayvan Beslenmesinde Kullanilır,

- Ekim Nöbeti Bitkisi Olarak Kullanılır,

- Arı Yetiştiriciliğinde Kullanııır,

- Sanayide Hammadde Olarak Kullanılır ve

- Bio-dizel Üretiminde Kullanılır.

\section{Bitkisel yağlar ve önemi}

Kimyasal olarak yağ; ya $\breve{g}$ asitlerinin trigliseridleri olarak bilinir ve üç yağ asidi ile bir gliserin molekülünün birleşmesinden meydana gelmiştir. Yağlar;

- Önemli bir enerji kaynağıdırlar,

- $\mathrm{A}, \mathrm{D}, \mathrm{E}$ ve $\mathrm{K}$ gibi yağda çözünen vitaminleri içerirler,

- Vücut yapısının gelişmesi için gerekli esansiyel (temel) yağ asitlerinin kaynağını teşkil ederler,

- Yemeklere lezzet ve tat kazandırırlar,

- Midenin boşalma süresini uzatarak acıkmayı geciktirirler,

- Organların diş etkilerden korunmasını sağlarlar,

- Sanayide hammadde olarak kullanılırlar ve

- Bio-dizel üretiminde kullanılırlar (Arıoğlu, 2014).

Yağlar, enerji kaynağı olarak insan beslenmesinde ayrı bir öneme sahiptirler. Zira; bir gram yağın vücutta yakılmas1 sonucu 9.3 kalorilik bir enerji ortaya çıkarılmasına rağmen, 1 gr proteinin sağladığı enerji miktarı 4.0 kalori ve 1 gr karbonhidratın sağladığı enerji miktarı ise 4.5 kaloridir (Arığlu, 2014). Normal bir insanın günlük faaliyetlerini yerine getirebilmesi için toplam 2800-3000 kaloriye gereksinim vardır. Bunun $\%$ 30-35'ini (850-900 kalori) yağlardan alması gerekmektedir.

\section{Dünya'da yağlı tohum ve ham yağ üretimi Yağlı tohum üretimi}

Dünya üzerinde yabani ve kültüre alınarak yetiştirilen tek ve çok yıllık birçok bitkinin etli meyve kısmı, çoğunlukla da tohumları değişik oranlarda yağ içermektedirler. Yeryüzünde tohumlarında yağ içeren çok sayıda bitki olmasına rağmen, bugün sanayide işlenerek tohumlarından yağ elde edilen bitkilerin başında; Soya, ayçiçeği, çiğit (pamuk), kolza, yerfistığı, susam, aspir, hintyağı, haşhaş, keten, kenevir, jojoba, mısır (mısır özünden), zeytin, hurma ve Hindistan cevizi gelmektedir. Bunlar içerisinden; Çiğit, haşhaş, keten, kenevir ve mısır farklı kullanım amacına yönelik olarak yetiştirilmekte, ancak yan ürün olarak tohumlarından yağ elde edilmektedir.

1965-2016 yılların kapsayan, son 50 yıllık dönem içerisinde dünya yağlı tohum üretimi ve üretiminde meydana gelen değişimler beşer yıllık dönemler halinde Çizelge 1'de verilmiş̧ir.

Çizelge 1'in incelenmesinden de görüleceği gibi, 1965 yılında dünya yağlı tohum üretimi 98.6 milyon ton iken (zeytin, hurma ve Hindistan cevizi hariç), 2016 yılında 554 milyon ton olarak gerçekleşmiştir. Son 50 y1llık dönemde dünya yağlı tohum üretiminde $\% 462$ 'lik bir artış sağlanmıştır. Yağlı tohum üretiminde en büyük artış kolza (\%1.208) ve soya (\%963) tohumunda olmuştur. 2016 yılı değerlerine göre 554 milyon ton olan dünya yağlı tohum üretiminin büyük bir kısmı soya (\%60.8) ve kolza ( \%12.3)'dan karşılanmıştır. 2016 yılı değerlerine göre dünya yağlı tohum üretiminin $\% 22.9$ 'u ABD, \%19.3'ü Brezilya, \%10.8 Arjantin, \%10.1'i Çin, $\% 6.7$ Hindistan ve geri kalan \%30.1'de diğer ülkelerde 
tarafindan üretilmiştir. Dünya yağlı tohum ticaretinin büyük bir kısmı bu ülkeler tarafindan yönlendirilmektedir. Ham protein oranı bakımından oldukça yüksek değerlere sahip olan yağlı tohum küspeleri, hayvan beslenmesi bakımından önemli bir yere sahiptir. Yılda toplam bir milyar ton karma yem üretimi yapıldığı tahmin edilmekte ve yaklaşık 300 milyon ton yağlı tohum küspesi kullanılmaktadır (Karakuş, 2014). Bu nedenlerden dolayı, yağlı tohum üretimi dünya tarımı ve ekonomisi açısından çok büyük öneme haizdir. 2013 yılı değerlerine göre ülkemizde işlenebilir tarım alanlarının ancak \%4.0'ünde yağlı tohumlu bitkiler yetiştirilirken, bu oran ABD'de \%20.9, Çin'de \%19.2, Brezilya'da \%28.2, Hindistan'da \%27.9 ve Arjantin'de \%21 olarak gerçekleşmiştir. AB ülkelerinde ise bu oranın $\% 30$ dolaylarında olduğu bildirilmektedir (Anonim,2016a).

Çizelge 1. Son 50 y1llık dönemde (1965-2016) dünyada yağlı tohum üretim miktarı (mil. ton), oransal değerler (\%) ve artış oranları (\%) (Anonim, 2016a).

\begin{tabular}{|c|c|c|c|c|c|c|c|c|}
\hline Y1llar & Ayçiçeği & Çiğit & Soya & Kolza & Yerfistığ 1 & Aspir & Susam & Toplam \\
\hline 1965 & 8.0 & 35.7 & 31.7 & 5.2 & 15.8 & 0.5 & 1.7 & 98.6 \\
\hline 1970 & 10.0 & 35.4 & 43.7 & 6.7 & 18.0 & 0.7 & 2.0 & 116.5 \\
\hline 1975 & 9.9 & 36.0 & 64.2 & 8.8 & 19.1 & 1.0 & 1.7 & 140.7 \\
\hline 1980 & 13.7 & 41.2 & 81.0 & 10.7 & 16.9 & 0.9 & 1.7 & 166.1 \\
\hline 1985 & 18.9 & 50.7 & 101.2 & 19.2 & 21.0 & 0.9 & 2.3 & 224.2 \\
\hline 1990 & 22.7 & 54.3 & 108.5 & 24.4 & 23.3 & 0.8 & 2.4 & 236.4 \\
\hline 1995 & 26.3 & 56.7 & 127.0 & 34.2 & 28.8 & 0.8 & 2.5 & 276.3 \\
\hline 2000 & 26.4 & 53.1 & 161.4 & 39.5 & 35.0 & 0.6 & 2.9 & 318.9 \\
\hline 2005 & 30.7 & 66.7 & 209.7 & 45.3 & 36.5 & 0.6 & 3.3 & 392.8 \\
\hline 2010 & 34.0 & 44.0 & 264.0 & 61.0 & 42.1 & 0.6 & 4.4 & 450.1 \\
\hline 2016 & 45.0 & 40.0 & 337.0 & 68.0 & 43.9 & 0.7 & 6.2 & 554.0 \\
\hline Artış oranı (\%) & $\mathbf{4 6 2}$ & $\mathbf{1 2 . 0}$ & $\mathbf{9 6 3}$ & $\mathbf{1 2 0 8}$ & $\mathbf{1 7 8}$ & $\mathbf{4 0}$ & $\mathbf{2 6 4}$ & $\mathbf{4 6 2}$ \\
\hline Oransal değer (\%)* & $\mathbf{8 . 1}$ & $\mathbf{7 . 2}$ & $\mathbf{6 0 . 8}$ & $\mathbf{1 2 . 3}$ & $\mathbf{7 . 9}$ & $\mathbf{0 . 1}$ & $\mathbf{1 . 1}$ & $\mathbf{1 0 0 . 0}$ \\
\hline
\end{tabular}

*\%2.5 (13.2 milyon ton)'ini de diğer yağlı tohumlar (zeytin, hurma ve coco hariç) oluşturmaktadır.

\section{Ham yağ üretimi}

Dünya üzerinde yabani ve kültüre alınarak yetiştirilen tek ve çok yıllık birçok bitkinin etli meyve kısmı, çoğunlukla da tohumları değiş̧ik oranlarda yağ içermektedirler. Bu nedenle, yağlı tohumlu bitkiler ham yağ üretiminde kullanılmak üzere yetiştirilirler. Dünya ham yağ üretiminin büyük bir kısmı (\%92.1) yağlı tohumlardan karşılanmaktadır. Son beş yıllık (20122016) döneme ait dünya bitkisel ham yağ üretim değerleri ile ürün cinslerine göre dağılımı Çizelge 2 'de verilmiştir.Çizelge 2'nin incelenmesinden de görüleceği üzere, son beş yıllık ortalama değerlere göre dünya bitkisel ham yağ üretimi 175 milyon ton olarak gerçekleşmiştir Dünya bitkisel ham yağ üretiminin $\% 27.8$ 'i soyadan, $\% 2.9$ 'u çiğitten, $\% 8.9$ 'u ayçiçeğinden, $\% 15.4$ 'ü kolzadan, \%33.2'si palmden ve \%11.8'i de diğer yağlı tohumlardan karşılanmıştır. Son beş yıllık dönem içerisinde dünya bitkisel ham yağ üretimi 162 milyon tondan, 187 milyon tona yükselmiştir (\%15.4 artış sağlanmıştır). Dünya bitkisel ham yağ üretimi bakımından; Endonezya, Çin, Malezya, AB, ABD, Arjantin ve Brezilya gibi ülkeler ilk suralarda yer almaktadır. Dünya bitkisel ham yağ üretiminin \%74.3'ü bu ülkeler tarafindan sağlanmaktadır. Dünya ortalaması olarak kişi başına düşen yıllık toplam yağ tüketimi 29.0 $\mathrm{kg}$ olarak gerçekleşmiştir. Bu miktar; Hindistan'da 15 $\mathrm{kg}$, Türkiye'de $21.9 \mathrm{~kg}$, Çin'de $26 \mathrm{~kg}$, ABD'de $57 \mathrm{~kg}$ ve $\mathrm{AB}$ ülkelerinde ise $60 \mathrm{~kg}$ olarak belirlenmiştir (Anonim, 2016a).

\section{Türkiye'de yağlı tohum ve ham yağ üretimi} Yağlı tohum üretimi

Yağlı tohum üretimi bakımından ülkemizde önemli bir potansiyel bulunmaktadır. Sahip olduğu farklı iklim ve toprak özellikleri nedeniyle Türkiye'de, Jojoba, Hurma ve Hindistan cevizi dışındaki yağlı tohumlu bitkilerin tamamı başarıyla yetişebilmektedir (Arıoğlu, 2014).

Çizelge 2. Son beş ylllık dönemde (2012-2016) dünya bitkisel ham yağ üretim (milyon ton) değerleri ve ürün cinslerine göre dağılımı (\%) (Anonim, 2016b).

\begin{tabular}{|c|c|c|c|c|c|c|c|}
\hline \multirow[b]{2}{*}{ Ürün cinsi } & \multicolumn{5}{|c|}{ Yıllara göre ham yağ üretimi (milyon ton/yıl) } & \multirow{2}{*}{$\begin{array}{l}\text { Ortalama } \\
\text { (mil. ton) }\end{array}$} & \multirow[b]{2}{*}{ O.D $(\%)^{*}$} \\
\hline & 2012 & 2013 & 2014 & 2015 & 2016 & & \\
\hline Soya & 43 & 45 & 49 & 52 & 54 & 48.6 & 27.8 \\
\hline Çiğit*** & 5 & 5 & 5 & 5 & 5 & 5.0 & 2.9 \\
\hline Ayçiçeği & 14 & 16 & 15 & 16 & 17 & 15.6 & 8.9 \\
\hline Kolza & 25 & 27 & 28 & 28 & 27 & 27.0 & 15.4 \\
\hline Palm & 56 & 59 & 52 & 59 & 65 & 58.2 & 33.2 \\
\hline Diğerleri & 19 & 20 & 28 & 17 & 19 & 20.6 & 11.8 \\
\hline Toplam & 162 & 172 & 177 & 177 & 187 & 175.0 & 100 \\
\hline
\end{tabular}

*O.D: Oransal değer (\%); **Çiğit: Pamuk tohumu 
1965-2016 yıllarını kapsayan, son 50 yıllık dönem içerisinde Türkiye yağlı tohum üretimi ve üretiminde meydana gelen değişimler beşer yıllık dönemler halinde Çizelge 3'de verilmiştir.

Çizelge 3. Son 50 yıllık dönemde (1965-2016) Türkiye'de yağlı tohum üretim miktar (1000 ton), artış oranları (\%) ve ürün cinslerine göre oransal değerler (\%) (Anonim, 2016c).

\begin{tabular}{|c|c|c|r|r|r|r|c|c|}
\hline Yıllar & Ayçiçeği & \multicolumn{1}{c|}{ Çĭgit } & \multicolumn{1}{|c|}{ Soya } & \multicolumn{1}{|c|}{ Kolza } & Yerfıstığı & Aspir & Susam & Toplam \\
\hline 1965 & 160 & 527.0 & 5.0 & 7.5 & 30.0 & - & 34.0 & 763.5 \\
\hline 1970 & 375 & 640.0 & 12.0 & 3.1 & 37.0 & - & 36.0 & 1103.1 \\
\hline 1975 & 488 & 768.0 & 6.8 & 0.5 & 40.0 & - & 33.0 & 1336.3 \\
\hline 1980 & 750 & 800.0 & 2.3 & 11.5 & 41.0 & - & 26.0 & 1630.8 \\
\hline 1985 & 800 & 828.0 & 25.0 & 0.5 & 59.0 & - & 45.0 & 1757.5 \\
\hline 1990 & 860 & 1047.4 & 162.0 & 2.1 & 63.0 & 0.14 & 39.0 & 2173.6 \\
\hline 1995 & 900 & 1262.6 & 5.0 & - & 70.0 & 0.13 & 30.0 & 2267.7 \\
\hline 2000 & 800 & 1295.1 & 44.5 & 0.2 & 78.0 & 0.02 & 23.0 & 2240.7 \\
\hline 2005 & 930 & 930.0 & 45.0 & 2.0 & 80.0 & 0.22 & 26.0 & 2013.2 \\
\hline 2010 & 1000 & 1000.0 & 55.0 & 110.0 & 97.3 & 26.00 & 23.4 & 2311.7 \\
\hline 2014 & 1200 & 1200.0 & 53.0 & 112.0 & 123.6 & 76.00 & 17.7 & 2882.3 \\
\hline 2015 & 1200 & 1000.0 & 161.0 & 120.0 & 147.5 & 70.00 & 18.5 & 2717.0 \\
\hline 2016 & 1250 & 1100.0 & 165.0 & 125.0 & 164.2 & 58.00 & 19.5 & 2881.7 \\
\hline Artış oranı (\%) & $\mathbf{6 1 8 . 2}$ & $\mathbf{1 0 8 . 7}$ & $\mathbf{3 2 0 0}$ & $\mathbf{1 5 6 6 . 7}$ & $\mathbf{4 4 7 . 3}$ & - & $\mathbf{( - )} \mathbf{4 2 . 6}$ & $\mathbf{2 7 7 . 4}$ \\
\hline Oransal değer (\%) & $\mathbf{4 3 . 4}$ & $\mathbf{3 8 . 2}$ & $\mathbf{5 . 7}$ & $\mathbf{4 . 3}$ & $\mathbf{5 . 7}$ & $\mathbf{2 . 0}$ & $\mathbf{0 . 7}$ & $\mathbf{1 0 0}$ \\
\hline
\end{tabular}

Çizelge 3'ün incelenmesinden de görüleceği gibi, Türkiye yağlı tohum üretimi 1965 yılında 763.500 ton iken, son 50 yıllık dönemde \%277.4'lük bir artışla 2016 yılında 2.881.700 ton'a ulaşmıştır. Yağlı tohum üretiminde en büyük artış soya (\%3200) ve kolzada (\%1566.7) olmuştur. Soya üretimi 1987 yılında 250 bin tonlara ulaşmış ancak, daha sonra uygulanan yanlış politikalar nedeniyle 30 bin tonlara kadar gerilemiştir. Son y1llarda uygulamaya konulan pirim sistemi ile üretimde önemli artışlar (2013 yılında 180 bin tonlara ulaşmış) sağlanmıştır. Bu durum diğer yağlı tohumlu bitkiler için de geçerli olmuştur. Zira; önceki yıllarda üretimi yok denecek kadar az olan kolza ve aspir üretimi, 2016 yılında sirasıyla 125 bin ton (kolza) ve 58 bin ton (aspir) olarak gerçekleşmiştir. Yağlı tohumlu bitkiler içerisinde susam üretimi diğer bitkilerin aksine yıldan yıla azalış göstermiştir.

Türkiye'de yağlı tohum denildiği zaman akla ayçiçeği ve çiğit gelmektedir. Zira bu iki ürün Türkiye yağlı tohum üretiminin \%81.6'sını oluşturmaktadır. Soya, kolza ve aspir üretiminde son yıllarda önemli artışlar gerçekleşmiştir. Türkiye'de yağlı tohum üretimine ayrılan alan, toplam ekilebilir alanların ancak \%4'ünü oluşturmaktadır. Bu nedenle yerli üretimden sağlanan yağlı tohum miktarı, ülke gereksinimlerini karşılayamadığ 1 için, her yıl yurt dişından binlerce ton yağlı tohum ve ham yağ ithal edilmektedir

\section{Ham yağ üretimi}

Ülkemizde yağlı tohum üretiminin yeterli olmaması nedeniyle, yerli üretime ilave olarak, yurt dışından yağlı tohum ithal edilerek, ham yağ üretiminde kullanılmaktadır. Aynı zamanda, yurt dışından doğrudan ham yağ ithal edilmek suretiyle, yurt içinde değerlendirilmektedir. Son beş y1llık dönemde (20122016) Türkiye'de bitkisel ham yağ üretim ile bu üretimin yerli ve yabancı kaynaklardan sağlanma oranları Çizelge 4'de verilmiştir.

Çizelge 4. Türkiye'de 2012-2016 yıllarını kapsayan son beş yıllık döneme ait bitkisel ham yağ üretim değerleri (1000 ton) (Anonim, 2016b)

\begin{tabular}{|c|c|c|c|c|c|c|c|}
\hline \multirow[b]{2}{*}{ Yillar } & \multirow{2}{*}{\begin{tabular}{|c|} 
Yerli \\
Tohumdan \\
Örretim (1000 \\
ton)
\end{tabular}} & \multirow{2}{*}{$\begin{array}{c}\text { Oransal } \\
\text { değer }(\%)\end{array}$} & \multicolumn{3}{|c|}{ İthal ham yağ üretimi (1000 ton) } & \multirow{2}{*}{$\begin{array}{c}\text { Oransal } \\
\text { Değer } \\
(\%)\end{array}$} & \multirow{2}{*}{$\begin{array}{l}\text { Toplam } \\
\text { Yağ } \\
\text { üretimi } \\
\text { (yerli + } \\
\text { ithal) }\end{array}$} \\
\hline & & & \begin{tabular}{|c|} 
İthal \\
tohumdan yağ \\
üretimi
\end{tabular} & $\begin{array}{c}\text { Doğrudan } \\
\text { ham yă̆ } \\
\text { ithalatı }\end{array}$ & $\begin{array}{c}\text { Toplam } \\
\text { ithal yağ } \\
\text { üretimi }\end{array}$ & & \\
\hline 2012 & 680 & 27.4 & 483 & 1.323 & 1.806 & 72.6 & 2.486 \\
\hline 2013 & 811 & 30.3 & 474 & 1.388 & 1.862 & 69.7 & 2.673 \\
\hline 2014 & 771 & 25.4 & 700 & 1.562 & 2.262 & 74.6 & 3.033 \\
\hline 2015 & 753 & 26.4 & 559 & 1.543 & 2.102 & 73.6 & 2.855 \\
\hline 2016 & 786 & 27.2 & 620 & 1.482 & 2.102 & 72.8 & 2.888 \\
\hline Ortalama & 760 & 27.3 & 567 & 1.460 & 2.027 & 72.7 & 2.787 \\
\hline
\end{tabular}


Çizelge 4'ün incelenmesinden de görüleceği üzere, son beş ylllık ortalama değerlere göre ülkemizde toplam ham yağ üretimi 2.787 .000 ton olup, bunun \%27.3'ü (760.000 ton) yerli tohumlardan ve \%72.7'si (2.027.000 ton) yurt dışından ithal edilen yağlı tohumlardan ve ham yağlardan karşılanmıştır. Yurt dışından ithal edilen toplam 2.027.000 ton bitkisel yağın, 567.000 tonu ithal yağlı tohumların yurt içinde işlenmesinden elde edilmiş, 1.460.000 tonu ise doğrudan ham yağ olarak ithal edilmiştir.

Türkiye'de yağlı tohum üretiminin yetersiz olması nedeniyle, her yıl yurt dışından önemli miktarlarda yağlı tohum ve türevleri ithal edilmiş ve bunun için yurt dışına yüksek miktarlarda döviz ödenmiş̧ir (petrolden sonra en fazla). Son on ylllık dönemde ortalama 2.327 bin ton yağlı tohum (Ayçiçeği, soya, pamuk, kanola ve aspir tohumu) ve 1.197 bin ton da ham yağ ithal edilmiş̧ir. Ayrıca, ülke hayvancılığının gelişmesine paralel olarak karma yem üretimi de artmakta ve yağlı tohum üretiminin yetersiz olması nedeniyle her y1l yurt dışından yıllık ortalama 1.260 bin ton yağlı tohum küspesi ithal edilmek durumunda kalınmaktadır. Son on y1llık ortalama değerlere göre toplamda 4.784 bin ton yağlı tohum ve türevleri ithal edilmiştir.

Ülkemizde yağlı tohum üretiminin yetersiz olması nedeniyle yurt dışından ithal edilen yağlı tohum ve türevleri iç̧in yurt dışına önemli miktarlarda döviz ödenmek zorunda kalınmıștır. 2007-2016 yıllarını kapsayan son on yıllık dönemde yurt dışından ortalama 1.295 mil. \$/yıl yağlı tohum ithalatı için, 1.356 mil. \$/yll ham yağ ve 435 mil.\$/y1l da küspe ithalatı için olmak üzere toplamda 3.086 mil. \$/yıl döviz ödenmiş̧ir.

\section{SONUÇ}

Yapılan hesaplamalara göre ülkemizde işlenebilir tarım alanlarının ancak \%4'lük kısmında yağlı tohum üretimi yapılmakta (bu oran $\mathrm{ABD}$ ve $\mathrm{AB}$ ülkelerinde yaklaşık \%30 dolaylarında gerçekleşmektedir), bu da yeterli olmamaktadır. 2020'li yıllarda, yağlı tohum üretiminin yeterli olabilmesi için, yağlı tohum ekim alanlarının \%15 düzeylerine ulaşması, diğer bir ifadeyle yağlı tohum üretiminin, 7-8 milyon tonların üzerine çıkartılması gerekmektedir. Bu amaca yönelik olarak, Türkiye'de yağlı tohum üretimini artırabilmek için; ayçiçeği, soya, kolza ve aspir gibi bitkilerin üretimini artırabilecek yeni alanlar belirlenmeli ve bu bitkilerin üretimlerinin yaygınlaşması için gerekli stratejiler geliştirilmelidir.
Yağlı tohumlu bitkilerin üretimi açısından ülkemizde var olan mevcut potansiyel değerlendirilerek, gereksinin duyulan yağlı tohumları kendimiz üretmek zorundayız. Aksi takdirde gelecekte ülke olarak çok büyük zorluklarla karşılaşabiliriz. Bugün yağlı tohum olarak en fazla ithalat yaptığımız Rusya ve Ukrayna gibi ülkeler, yağlı tohum yerine, ham yağ ihraç etmeye başlamışlardır. Bu durumun devam etmesi halinde, yılda yaklaşık 2.5 milyon ton tohum işleme kapasiteli ham yağ üretim tesislerimiz atıl duruma düşecektir. Ayrıca, ham yağ işleme (kırma) tesislerinin durması halinde, küspe ihtiyacının karşılanmasında tamamen dıșarıya bağımlı hale gelinecek, gelecek dönemlerde de ham yağ bulmak bile zorlaşacak ve rafine edilmiş ambalajlı yemeklik yağ ithal edilmek zorunda kalınacaktır. Bugün \%55-65 olan kapasite kullanımı (yağ sanayindeki) çok aşağılara düşecektir.

Yapılan araştırmalar göstermiş̧tir ki; palm ve Hindistan cevizi dışında kalan, yağlı tohumlu bitkilerin tümü, yazlık veya kışlık olarak ülkemizde yetişebilmektedir. Yağlı tohumlu bitkilerin üretimi açısından ülkemizdeki mevcut potansiyelin değerlendirilmesi halinde, hem ülkemizin gereksinim duyduğu yağ ihtiyacı karşılanmış olacak ve hem de \%35-45 atıl kapasite ile çalışan yağ sektörüne, büyük katkılar sağlanmış olacaktır.

\section{KAYNAKLAR}

Anonim 2016a. İstatistik Bölümü İnternet Sitesi, http://www.fao.org

Anonim 2016b. Bitkisel Yağ Sanayicileri Derneği Türkiye İstatistikleri, www.bysd.org

Anonim 2016c. TUIKK Yayınları, Ankara.

Arıoğlu HH, Kolsarıcı Ö, Göksu AT, Güllüoğlu L. Arslan M, Çalışkan M, Söğüt T, Kurt C, Arslanoğlu F 2010. Yă Bitkileri Üretiminin Artırılması Olanakları. Ziraat Mühendisliği VII. Teknik Kongresi Bildiriler Kitabi-1, s. 361-376, Ankara

Arıoğlu HH 2014. Yağ Bitkileri Yetiştirme Ve Islahı Ders Kitabı.Genel Yayın No:220, Ders Kitapları Yayın No:A-70. Adana, $204 \mathrm{~s}$.

Karakuş MÜ 2014. 12. Uluslararası Yem Kongresi Aç1lış Konuşması. Türkiye Yem Sanayicileri Birliği Dergisi. Sayı.70:29-40s, Ankara

Kolsaracı Ö, Kaya KD, Göksoy AT, Arığlu H, Kulan EG, Day S 2015. Yağlı Tohum Üretiminde Yeni Arayışlar. Ziraat Mühendisliği VIII. Teknik Kongresi Bildiriler Kitabı-1, s. 401-425, Ankara 